\title{
ANALISA DETEKSI GELOMBANG QRS UNTUK MENENTUKAN KELAINAN FUNGSI KERJA JANTUNG
}

\author{
Evrita Lusiana Utari \\ Jurusan Teknik Elektro, Fakultas Sains \& Teknologi Universitas Respati Yogyakarta \\ Jl. Laksda Adisucipto Km 6,3 Depok, Sleman, Yogyakarta 55281 Telp 0274489780 \\ E-mail: evrita_lusiana@yahoo.com
}

\begin{abstract}
Mortality rate by heart disease in Indonesia is up to 26\%. To prevent the higher of mortality rate by heart disease, an early examination for heart can be done by taking the record of electrocardiograph. The record was analyzed to know the heart rhythm that can be indication of heart disorder. By applying the warning of heart disorder, the heart condition and the treatment can be known rapidly.

Electrocardiography record can be done in a short time, i.e. for 5 minutes (short term). Analyzing method in the time domain is the simplest way to analyze the variation of the heart rate. Analyzing in the time domain for $R$ interval and the heart rate can be done by histogram and statistical analysis. Measurement method in the time domain is divided into two parts statistically, i.e. directly measurement for normal condition in $R$ interval or the heart rate include the average value, and the standard deviation.

The wavelet method was used in the QRS detection method in this research. Wavelet was designed to signal data processing, data filtering, thresholding, and histogram, to acquire the average of QRS wave, and its deviation standard. The benefit of the wavelet method can obtained the negative deflection value for $Q$ wave with the amplitude $25 \%$ of $R$ wave, $R$ wave obtained positive deflection with the amplitude 1,6-3 $\mathrm{mV}$, and negative deflection for $S$ wave has the amplitude between $0,1 \mathrm{mV}$ up to $0,5 \mathrm{mV}$.
\end{abstract}

Keyword: QRS, detection, EKG, Signal Processing.

\section{PENDAHULUAN}

Organ utama dalam tubuh manusia salah satunya adalah jantung, jika terjadi kelainan kerja pada jantung akan berdampak pula pada aliran darah yang ke seluruh tubuh yang pada kategori tertentu bisa berakibat fatal. Terjadinya serangan penyakit jantung sebenarnya didahului dengan indikasi kelainan kerjanya yang bisa diamati dari ritme yang terjadi. Dengan menerapkan sistem peringatan adanya kelainan kerja jantung akan bisa diketahui secara cepat kondisi serta penanganannya. Untuk mendeteksi adanya kelainan kerja jantung maka harus diketahui terlebih dahulu ritme kerja jantung itu sendiri.

Bagian sinoatrial (SA) pada jantung berfungsi sebagai pace maker yang akan menghasilkan pulsa listrik pemicu kontraksi pada otot jantung dibagian serambi kemudian diteruskan melalui Atrioventriculer (AV) menuju serabut purkinje yang akan memicu kontraksi otot jantung tersebut dibagian bilik (Skill lab, 2009).

Elektrokardiografi (EKG) adalah alat untuk mengukur biopotensial listrik jantung pada manusia. Potensial elektrik jantung dipicu oleh potensial aksi yang dibangkitkan oleh SA node dan AV node, sehingga pola potensial yang terbentuk dan yang terdeteksi oleh elektrode permukaan akan mengikuti depolarisasi sel jantung selama dilalui oleh potensial aksi ini. Sementara jantung dalam keadaan istirahat, semua sel terpolarisasi sehingga setiap sel adalah negatif terhadap luarannya. Depolarisasi pertama muncul pada SA node, membuat bagian luar jaringan relatif lebih negatif terhadap sel didalam, 
juga akan lebih negatif dibandingkan dengan jaringan yang belum dipolarisasi. Hal ini menghasilkan arus ionik $I$ yang menyebabkan lengan kiri terukur lebih positif dibandingkan lengan kanan.

Pengetahuan tentang aktifitas elektrik jantung sangat dibutuhkan dalam operasi. Suatu gangguan elektrik yang sangat kecil dapat menyebabkan jantung berhenti memompa darah yang diperlukan untuk menjaga kehidupan manusia. Pada anatomi dan fungsi jantung, jantung berfungsi sebagai pemompa darah dengan empat kamar pada sistem peredaran darah. Ventrikel berperan dalam pemompaan darah, sedangkan antrium berfungsi untuk menyimpan darah selama ventrikel memompa.
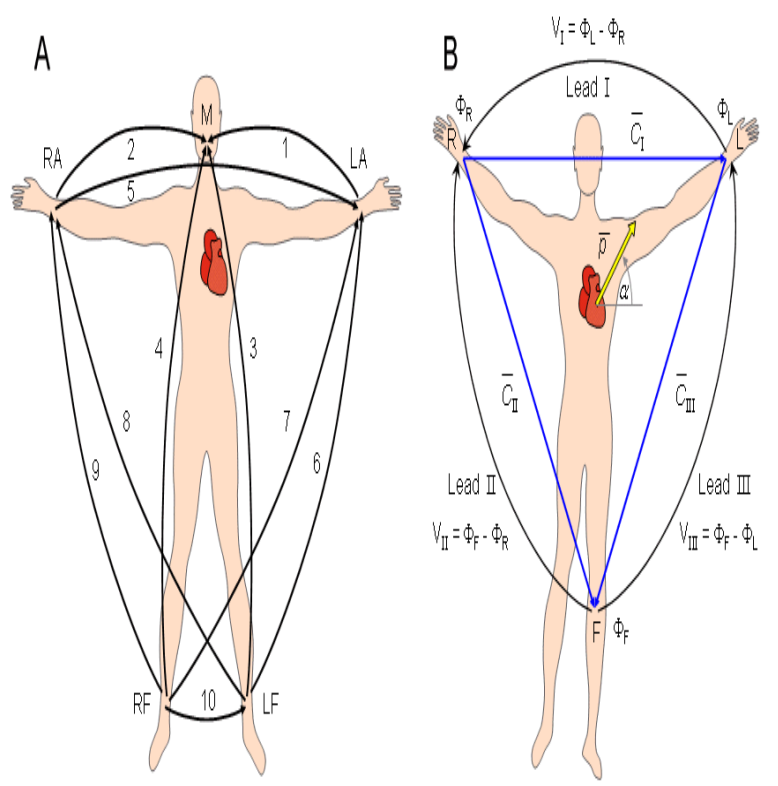

Gambar 1. Pemasangan Lead EKG.

Sistem EKG standart terdiri dari 12 leads (I, II, III, aVR, aVL, aVF, V1, V2, V3, V4, V5 dan V6). Setiap lead mencatat aktivitas elektrik jantung dari posisi anatomi yang berbeda. Identitas dari perubahan miokardium pada lead tertentu dapat membantu menentukan kondisi patologis. Amplitudo normal dari gelombang P kurang lebih $3 \mathrm{~mm}$, durasi normal dari gelombang Padalah 0,04 - 0,11 detik. Gelombang P yang lebih dari nilai ini diketahui adanya deviasi dari normal. Interval PR diukur dari naiknya gelombang $\mathrm{P}$ ke sambungan $\mathrm{QR}$ dan normalnya sekitar 0,12 dan 0,20 detik.

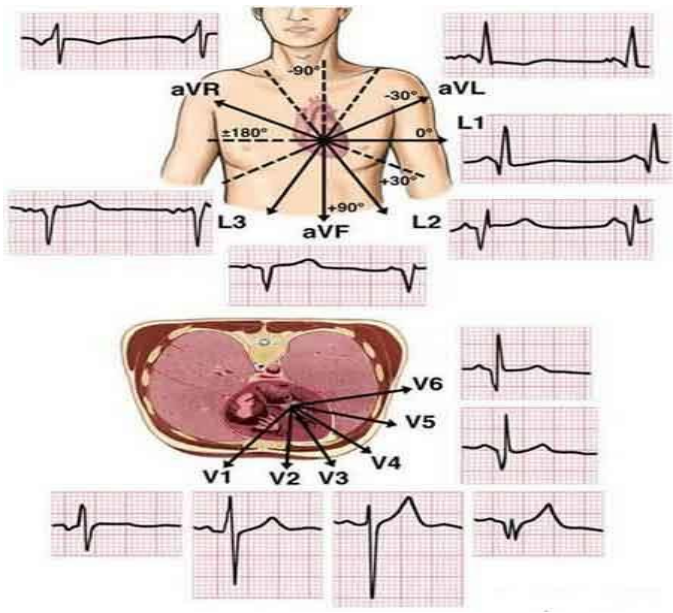

Gambar 2. Pola Gelombang Sinyal Kardiografi.

Interval PR merepresentasikan waktu transmisi impuls dari nodus SA ke nodus AV. Adanya kelambatan pada nodus AV untuk memungkinkan pengisisna ventricular yang kuat untuk mempertahankan stoke volume yang normal (jumlah darah yang dikeluarkan setiap kontraksi). Kompleks QRS mengandung gelombang dan segmen yang berbeda, yang dapat dievalusi secara terpisah. Kompleks QRS normal berada pada range 0,06 - 0,10 detik.

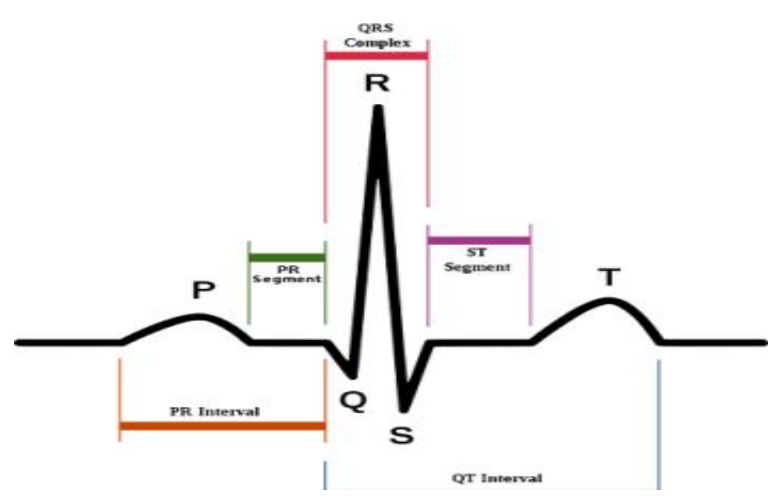

Gambar 3. Gelombang QRS.

Gelombang Q adalah penurunan pertama setelah gelombang $\mathrm{P}$, biasanya dalamnya kurang dari $3 \mathrm{~mm}$. Gelombang Q yang sangat defleksi merupakan keadaan yang tidak normal pada jantung yang sehat. Gelombang 
Q patologis biasanya mengidentifikasikan adanya old MI. Gelombang R merupakan defleksi positif pertama setelah gelombang $\mathrm{P}$, tinggi gelombang $\mathrm{P}$ pada kondisi normal adalah $5-10 \mathrm{~mm}$.

Peningkatan dan penurunan amplitudo menjadi sangat signifikan pada beberapa kondisi penyakit. Hipertrofi ventrikular akan menimbulkan gelombang $\mathrm{R}$ yang sangat tinggi karena otot hipertrofi memerlukan arus listrik yang sangat kuat untuk depolarisasi. Segmen ST dimulai di akhir gelombang S, merupakan defleksi negatif pertama setelah gelombang $\mathrm{R}$ dan berakhir pada peningkatan gelombang T. Gelombang T harus selalu ada, dimana gelombang $\mathrm{T}$ tersebut merepresentasikan repolarisasi serabut miokardium atau keadaan istirahat dari kerja miokardium. Gelombang $\mathrm{T}$ normal tidak boleh istirahat lebih dari $5 \mathrm{~mm}$ pada semua lead, kecuali lead precordial (V1 sampai dengan V6 disini dapat istirahat lebih dari 10 $\mathrm{mm})$.

Lebih dari tiga dekade telah dilakukan penelitian untuk mendeteksi QRS kompleks dimana telah banyak metode yang ditemukan seperti Pan dan Tompkins yang mengusulkan suatu algoritma untuk mengenai QRS kompleks yang biasa disebut metode PT. Kemudian Yun chi dan Wen June Wang mengusulkan suatu metode baru yang dikatakan sebagai metode yang simpel dan reliabel karena menggunakan algoritma yang cepat dan sederhana serta tidak membutuhkan perhitungan matematika rumit.

Elektrokardiograf merupakan merupakan alat bantu dokter untuk mengetahui aktivitas listrik jantung, yang merekam aktivitas kelistrikan jantung dalam waktu tertentu. Namanya terdiri atas sejumlah bagian yang berbeda: elektro, karena berkaitan dengan elektronika, kardio, kata Yunani untuk jantung, gram, sebuah akar Yunani yang berarti "menulis". Analisis sejumlah gelombang dan vektor normal depolarisasi dan repolarisasi menghasilkan informasi diagnostik yang penting. Adapun fungsi dari elektrokardiogram :

- Merupakan standar emas untuk diagnosis aritmia jantung.

- EKG memandu tingkatan terapi dan risiko untuk pasien yang dicurigai ada infark otot jantung akut.

- EKG membantu menemukan gangguan elektrolit (mis. hiperkalemia dan hipokalemia).

- EKG memungkinkan penemuan abnormalitas konduksi (mis. blok cabang berkas kanan dan kiri).

- EKG digunakan sebagai alat tapis penyakit jantung iskemik selama uji stres jantung.

- EKG kadang-kadang berguna untuk mendeteksi penyakit bukan jantung (mis. emboli paru atau hipotermia).

- Monitor EKG modern memiliki banyak penyaring untuk pemrosesan sinyal. Yang paling umum adalah mode monitor dan mode diagnostik. Dalam mode monitor, penyaring berfrekuensi rendah (juga disebut penyaring bernilai tinggi karena sinyal di atas ambang batas bisa lewat) diatur baik pada $0,5 \mathrm{~Hz}$ maupun 1 $\mathrm{Hz}$ dan penyaring berfrekuensi tinggi (juga disebut penyaring bernilai rendah karena sinyal di bawah ambang batas bisa lewat) diatur pada $40 \mathrm{~Hz}$. Hal ini membatasi EKG untuk pemonitoran irama jantung rutin. Penyaring bernilai tinggi membantu mengurangi garis dasar yang menyimpang dan penyaring bernilai rendah membantu mengurangi bising saluran listrik 50 atau $60 \mathrm{~Hz}$ (frekuensi jaringan saluran listrik berbeda antara 50 dan $60 \mathrm{~Hz}$ di sejumlah negara). Dalam mode diagnostik, penyaring bernilai tinggi dipasang pada $0,05 \mathrm{~Hz}$, yang memungkinkan segmen ST yang akurat direkam. Penyaring bernilai rendah diatur pada 40,100, atau $150 \mathrm{~Hz}$. Sebagai akibatnya, tampilan EKG mode monitor banyak tersaring daripada mode diagnostik, karena bandpass-nya lebih sempit. 
Dalam EKG terdapat kata sadapan memiliki 2 arti pada elektrokardiografi: bisa merujuk ke kabel yang menghubungkan sebuah elektrode ke elektrokardiograf, atau (yang lebih umum) ke gabungan elektrode yang membentuk garis khayalan pada badan di mana sinyal listrik diukur. Lalu, istilah benda sadap longgar menggunakan arti lama, sedangkan istilah 12 sadapan EKG menggunakan arti yang baru. Nyatanya, sebuah elektrokardiograf 12 sadapan biasanya hanya menggunakan 10 kabel/elektroda. Definisi terakhir sadapan inilah yang digunakan di sini.

\section{TINJAUAN PUSTAKA}

Beberapa penelitian yang telah dilakukan dengan implementasi pedektesian gelombang QRS komplek pada sistem peringatan kelainan kerja jantung nernasis mikrokontroler oleh Hendriyawan (2012) dalam penelitian tersebut dengan mencari nilai lokal maksimal gelombang QRS komplek untuk mengukur jarak waktu antar singleton. Selanjutnya penelitian dengan menggunakan metode identifikasi sinyal kardiografi ditunjukkan dengan perkembangan pertama kali oleh Ranjith (2006) yang melakukan penelitian dengan frekuensi $150 \mathrm{~Hz}$. Penelitian tentang analisis gelombang elektrokardiografi dengan menggunakan gelombang-singkat mexican hat yang ditambahkan dengan metode filter bank, dilaporkan mempunyai sensitivitas sebesar $87,5 \%$. Penelitian selanjutnya dilakukan dengan menggabungan metode gelombang-singkat morlet dengan metode neuro fuzzy untuk mendeteksi sinyal elektrokardiogram normal yang dilaporkan mempunyai sensitivitas sebesar $87,8 \%$ (Mehmet, 2007).

Metode pendeteksian elektrokardiografi tanpa menggunakan pre-prosesing adalah algoritma kupev. Algoritma kupev dilaporkan mempunyai sensitivitas sebesar 90\% (Darrington, 2009). Penelitian dengan menggunakan metode transformasi wavelet diskrit untuk mendeteksi sinyal elektrokardiografi normal dilaporkan mempunyai sensitivitas sebesar 96,2\% (Ubeyli, 2010).

Pengenalan pola sinyal seismik dengan menggunakan wavelet pada aktivitas gunung berapi (Utari, 2013). Dengan alih ragam gelombang singkat ini dimungkinkan pelokasian frekuensi-waktu. Metode Thresholding, bertujuan untuk membatasi dan menghilangkan bagian - bagian pada sinyal yang dianggap tidak banyak mengandung informasi penting. Dengan cara menentukan nilai parameter data, maka bagian-bagian yang dibatasi tersebut dapat dianggap sebagai derau yang tercampur.

Pengenalan signal EKG menggunakan dekomposisi paket wavelet dan k-means clustering (Rizal, 2008) pada penelitian tersebut dilakukan pengenalan kelainan penyakit jantung berdasarkan sinyal EKG dengan menggunakan dekomposisi wavelet. Sinyal tersebut didekomposisi hingga level 5 dengan tingkat akurasi 94,4\%.

\section{PEMBAHASAN}

\subsection{Teknik - Teknik Elektrokardiografi}

Terdapat tiga teknik yang digunakan dalam elektrokardiografi meliputi :

1. Standart clinical ECG ini menggunakan teknik 10 elektrode dengan 12 lead yang ditempatkan pada titik - titik tubuh tertentu. Teknik ini digunakan untuk menganalisa pasien.

2. Vectorcardiogram, teknik ini menggunakan tiga elektroda yang ditempatkan pada titik-titik tubuh tertentu. Teknik ini menggunakan pemodelan potensial tubuh vektor tiga dimensi dengan menggunakan sandapan baku bipolar (Einthoven). Dari sini akan dihasilkan gambar grafis dari eksitansi jantung.

3. Monitoring ECG, teknik ini menggunakan 1 atau 2 elektroda yang ditempatkan pada titik - titik tubuh tertentu. Teknik ini digunakan untuk memonitor pasien dalam jangka panjang. 
4. Standart clinical ECG ini menggunakan teknik 10 elektrode dengan 12 lead yang ditempatkan pada titik-titik tubuh tertentu. Teknik ini digunakan untuk menganalisa pasien.

5. Vectorcardiogram, teknik ini menggunakan tiga elektroda yang ditempatkan pada titik-titik tubuh tertentu. Teknik ini menggunakan pemodelan potensial tubuh vektor tiga dimensi dengan menggunakan sandapan baku bipolar (Einthoven). Dari sini akan dihasilkan gambar grafis dari eksitansi jantung.

6. Monitoring ECG, teknik ini menggunakan 1 atau 2 elektroda yang ditempatkan pada titik-titik tubuh tertentu. Teknik ini digunakan untuk memonitor pasien dalam jangka panjang.

\subsection{Karakteristik dan Parameter- Parameter dalam EKG}

Sinyal EKG terdiri dari gelombang $\mathrm{P}$, kompleks QRS, dan gelombang T digunakan untuk mendeteksi kelainan jantung atau aritmia. Urutan terjadinya sinyal EKG yang dapat menimbulkan gelombang $\mathrm{P}$, kompleks QRS, dan gelombang $\mathrm{T}$ (dengan deskripsi yang terdapat dalam tabel 1. Parameter EKG).

Tabel.1 Parameter EKG

\begin{tabular}{|c|c|c|}
\hline Defleksi & Deskripsi & Nilai \\
\hline Gelombang P & $\begin{array}{l}\text { Gelombang EKG yang pertama dilihat } \\
\text { dengan ciri-ciri lengkung kecil, defleksi } \\
\text { positif. }\end{array}$ & Amplitudo $<0,3 \mathrm{mV}$ \\
\hline Interval PR & $\begin{array}{l}\text { Jarak antara awal gelombang P dengan } \\
\text { awal kompleks QRS, pengukuran waktu } \\
\text { antara gelombang depolarisasi dari } \\
\text { atrium ke ventrikel. }\end{array}$ & Durasi $0,12-0,2$ detik \\
\hline Interval QRS & $\begin{array}{l}\text { - Gelombang Q: defleksi negatif } \\
\text { - Gelombano R. defleksi nositif }\end{array}$ & $\begin{array}{l}\text { - Amplitudo } 25 \% \text { dar } \\
\text { gelombang R amplitudo } \\
25 \% \text { dari gelombang R. }\end{array}$ \\
\hline & - Gelombang S: defleksi negatif & $\begin{array}{l}\text { - Amplitudo } 1,6-3 \mathrm{mV} \\
\text { - Amplitudo } 0,1-0,5 \mathrm{mV} \\
\text { setelah gelombang R. }\end{array}$ \\
\hline Segmen ST & $\begin{array}{l}\text { Jarak antara gelombang } \mathrm{S} \text { dan awal } \\
\text { gelombang T; Pengukuran waktu anatara } \\
\text { depolarisasi ventrikel dan awal } \\
\text { repolarisasi ventrikel }\end{array}$ & Durasi $0,05-0,15$ detik. \\
\hline Gelombang $\mathrm{T}$ & $\begin{array}{l}\text { Lengkung positif setelah kompleks QRS } \\
\text { yang memrepresentasikan repolarisasi } \\
\text { ventrikel. }\end{array}$ & Amplitudo 0,1 - 0,5 mV \\
\hline Interval QT & $\begin{array}{l}\text { Pengukuran waktu dari awal QRS sampai } \\
\text { akhir gelombang } \mathrm{T} \text { yang } \\
\text { merepresentasikan aktivitas. }\end{array}$ & $\begin{array}{l}\text { Ventrikel yang berdurasi } \\
0,35-0,44 \text { detik. }\end{array}$ \\
\hline
\end{tabular}

\subsection{Analisa EKG pada Domain Waktu}

Metode analisa pada domain waktu merupakan metoda paling sederhana untuk analisa variasi kecepatan detak jantung.
Analisa domain waktu untuk interval $\mathrm{R}$ dan kecepatan detak dengan analisa histogram, dan statistik. Metoda pengukuran pada domain waktu secara statistik dibagi dua 
bagian yaitu: pengukuran secara langsung kondisi normal $(\mathrm{N})$ interval $\mathrm{R}$ atau kecepatan detak jantung meliputi nilai rata-rata, dan standar deviasi.

\section{Gelombang P}

Selama depolarisasi atrium normal, vektor listrik utama diarahkan dari nodus SA ke nodus AV, dan menyebar dari atrium kanan ke atrium kiri. Vektor ini berubah ke gelombang $\mathrm{P}$ di EKG, yang tegak pada sadapan II, III, aVF (karena aktivitas kelistrikan umum sedang menuju elektrode positif di sadapan-sadapan itu), dan membalik disadapan aVR (karena vektor ini sedang berlalu dari lektrode positif untuk sadapan itu). Sebuah gelombang $\mathrm{P}$ harus tegak di sadapan II dan aVF dan terbalik di sadapan aVR untuk menandakan irama jantung sebagai Irama Sinus.

- Hubungan antara gelombang P dan kompleks QRS membantu membedakan sejumlah aritmia jantung.

- Bentuk dan durasi gelombang P dapat menandakan pembesaran atrium.

\section{Interval PR}

Interval PR diukur dari awal gelombang $P$ ke awal kompleks QRS,yang biasanya panjangnya 120-200 ms. Pada pencatatan EKG, ini berhubungan dengan 3-5 kotak kecil.

- Interval PR lebih dari $200 \mathrm{~ms}$ dapat menandakan blok jantung tingkat pertama.

- Interval PR yang pendek dapat menandakan sindrom pra-ektasi melalui jalur tambahan yang menimbulkan pengaktifan awal ventrikel, seperti yang terlihat di Sindrom Wolff - Parkinson White.

- Interval PR yang bervariasi dapat menandakan jenis lain blok jantung.

- Depresi segmen PR dapat menandakan lesi atrium atau perikarditis.

- Morfologi gelombang P yang bervariasi pada sadapan EKG tunggal dapat menandakan irama pacemaker ektopik seperti pacemaker yang menyimpang maupun takikardi atrium multifokus.

\section{Kompleks QRS}

Kompleks QRS adalah struktur EKG yang berhubungan dengan depolarisasi ventrikel. Karena ventrikel mengandung lebih banyak massa otot dari pada atrium, kompleks QRS lebih besar dari pada gelombang P. Disamping itu karena sistem HIS / Purkinje mengkoordinasikan depolarisasi ventrikel, kompleks QRS cenderung memandang tegak daripada membudar karena pertambahan kecepatan konduksi. Kompleks QRS yang normal berdurasi $0,06-0,1 \quad \mathrm{~s}(60-100 \mathrm{~ms}) \quad$ yang ditunjukkan dengan 3 kotak kecil atau kurang, namun setiap ketidak normalan konduksi bisa lebih panjang, dan menyebabkan perluasan komples QRS.

- Durasi, amplitudo , dan morfologi komples QRS berguna untuk mendiagnosis aritmia jantung, abnormalitas konduksi, hipertrofi ventrikel, infark otot jantung, gangguan elektrolit, dan keadaan sakit lainnya.

- Gelombang Q bisa normal (fisiologis) atau patologis. Bila ada, gelombang $\mathrm{Q}$ yang normal menggambarkan depolarisasi septum interventriculare.

- Gelombang Q lebih besar dari pada 1/3 tinggi gelombang $\mathrm{R}$, berdurasi lebih besar daripada $0,04 \mathrm{~s}(40 \mathrm{~ms})$, atau disadapan prekordial kanan dianggap tidak normal, dan mungkin menggambarkan infark miokardium.

\section{METODE PENELITIAN}

Penelitian ini menggunakan 5 jenis EKG diperoleh dari RSUD Panembahan Senopati, yang menggambarkan kondisi jantung berbeda, yakni Normal, Ventrikular Hypertrophy, Atrial Tachycardia, dan Myocardial Infarctio. 


\subsection{Alat Penelitian}

Alat yang digunakan untuk melaksanakan penelitian ini menggunakan perangkat lunak program Matlab (Matrix Laboratory). Matlab merupakan perangkat lunak matematis yang menggunakan vektor dan matrik sebagai elemen data utama. Perangkat ini diciptakan di Universitas Mexico dan Universitas Stanford pada tahun 70-an yang kemudian dikembangkan dan disempurnakan hingga saat ini. Matlab menyediakan fasilitas - fasilitas untuk komputasi, visualisasi dan pemograman. Selain itu Matlab juga memiliki beberapa fitur yang dikelompokkan berdasarkan aplikasi tertentu yang dikenal dengan Toolbox. Toolbox yang penting dalam penelitian ini adalah Toolbox Wavelet, dan Toolbox Signal Processing.

\subsection{Tahapan - tahapan Penelitian}

Penelitian ini dilakukan dengan tahapantahapan mulai penyiapan data sinyal kardiografi, pengolahan sinyal, filtering, deteksi tepi, dan analisa hasil deteksi.

Tahapan penyiapan data sampel sinyal kardiografi dalam penelitian ini dengan cara melakukan pengambilan gambar, kemudian melakukan seleksi kualitas dari hasil gambar. Pada pra-pemrosesan sinyal EKG di rubah ke dalam bentuk citra.

\subsubsection{Filtering}

Untuk mengatasi noise tersebut perlu dilakukan usaha untuk memperbaiki kualitas dari gelombang QRS tersebut. Salah satunya adalah dengan filtering gelombang baik secara linear maupun secara non - linear. Mean filter merupakan salah satu filtering linear yang berfungsi untuk memperhalus dan menghilangkan noise pada suatu sinyal yang bekerja dengan menggantikan intensitas nilai pixel dengan rata-rata dari nilai pixel tersebut dengan nilai pixel - pixel tetangganya.

Median filter adalah salah satu filtering non-linear yang mengurutkan nilai intensitas sekelompok pixel, kemudian mengganti nilai pixel yang diproses dengan nilai mediannya. Median filter telah digunakan secara luas untuk memperhalus dan mengembalikan bagian dari citra yang mengandung noise yang berbentuk bintik putih.

\subsubsection{Deteksi tepi}

Tepian dari suatu citra mengandung informasi penting dari citra bersangkutan. Tepian citra dapat merepresentasikan objekobjek yang terkandung dalam citra tersebut, bentuk, dan ukurannya serta terkadang juga informasi tentang teksturnya. Tepian citra adalah posisi di mana intesitas pixel dari citra berubah dari nilai rendah ke nilai tinggi atau sebaliknya. Deteksi tepi umumnya adalah langkah awal melakukan segmentasi citra. Tujuan deteksi tepi meningkatkan penampakan garis batas suatu daerah atau objek di dalam citra, mencirikan batas objek dan berguna untuk proses segmentasi dan identifikasi objek dan karena termasuk dalam komponen berfrekuensi tinggi, perlu filter high-pass.

Arah dari tepian citra bermacam macam. Ada yang lurus dan ada yang dapat digunakan untuk mendeteksi berbagai macam jenis tepian. Setiap teknik memiliki keunggulan masing-masing. Satu teknik deteksi tepi mungkin dapat bekerja sangat baik dalam suatu aplikasi tertentu namun sebaliknya belum tentu dapat bekerja secara maksimal dalam aplikasi lainnya. Tepian citra dapat dilihat melalui perubahan intensitas pixel pada suatu area. Berdasarkan perbedaan perubahan intensitas tersebut, tepian dapat dibagi menjadi 4 jenis, yaitu :

1. Step merupakan tepian yang terbentuk dari perubahan intensitas citra secara signifikan dari tinggi rendah ataupun sebaliknya.

2. Ramp merupakan tepian yang terbentuk dari perubahan intensitas citra secara perlahan. Perubahan secara perlahan dapat dilihat pada bentuk kurva yang semakin tinggi dengan perubahan kontinu. 
3. Line merupakan tepian yang ditandai dengan adanya perubahan intensitas secara drastis dari intensitas rendah tinggi - rendah atau sebaliknya.

4. Step - line merupakan gabungan dari tepian jenis step dan line. Tepian jenis ini ditandai dengan peningkatan intensitas yang tajam dalam interval tertentu kemudian ditandai dengan penurunan yang tidak signifikan, sehingga perubahan intensitas selanjutnya berlangsung stabil.

Analisa deteksi berdasarkan nilai konfigurasi yang telah ditentukan. Nilai tersebut dapat dilihat pada tabel 2 .

Proses pengolahan data dapat dilihat pada Gambar 4, dengan awal adalah pemilihan citra sinyal, yang kemudian dilanjutkan dengan pengolahan dan filtering data. Selanjutnya proses deteksi.

Tabel 2. Konfigurasi pada EKG

\begin{tabular}{cl}
\hline No & \multicolumn{1}{c}{ Jenis Konfigurasi EKG } \\
\hline 1 & Gelombang P : Proses depolarisasi atrium \\
2 & Gelombang QRS : Proses depolarisasi ventrikel \\
3 & $\begin{array}{l}\text { Gelombang Q: Defleksi negative pertama pada } \\
\text { gelombang QRS }\end{array}$ \\
4 & $\begin{array}{l}\text { Gelombang R: Defleksi positif pertama pada } \\
\text { gelombang QRS }\end{array}$ \\
5 & $\begin{array}{l}\text { Gelombang S : Defleksi negative setelah } \\
\text { gelombang R }\end{array}$ \\
6 & $\begin{array}{l}\text { Gelombang T : Proses repolarisasi ventrikel } \\
7\end{array}$ \\
Interval PR : Diukur dari permulaan gelombang \\
P sampai permulaan gelombang QRS
\end{tabular}

8 Segmen ST : Diukur dari akhir gelombang QRS sampai permulaan gelombang $\mathrm{T}$

\section{Nilai}

Nilai normal lebar $\geq 0,12$ detik

Tinggi $\leq 0,3$ miliVolt

Selalu (+) di lead II

Selalu (-) di lead aVR

Nilai normal lebar 0,06-0,12 detik

Tinggi tergantung lead

Nilai normal lebar $\leq 0,04$ detik

Dalamnya $<1 / 3$ tinggi $\mathrm{R}$

\section{Nilainya +}

Di lead aVR, V1 dan V2 terlihat lebih dalam, di lead V4, V5, dan V6 makin menghilang atau berkurang dalamnya.

Umumnya gelombang $\mathrm{T}$ positif di hampir semua lead kecuali di aVR

Nilai normal antara $0,12-0,2$ detik

Normalnya isoelektrik, tetapi pada lead precordial bervariasi $-0,5$ samapai $2 \mathrm{~mm}$.

Segmen ST diatas elektrik disebut ST elevasi.

Segmen ST dibawah garis Isoelektrik disebut ST depresi.

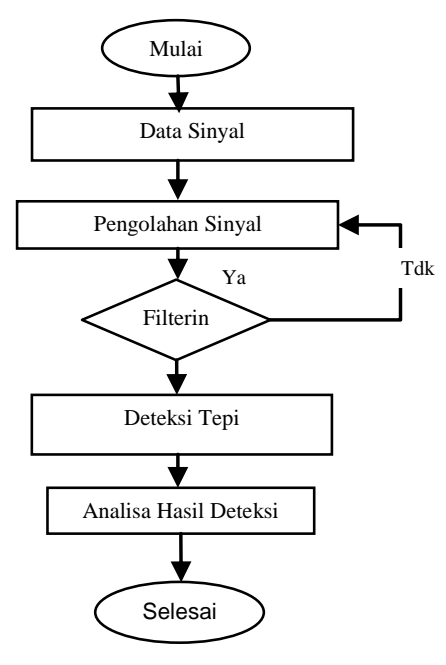

Gambar 4 Diagram Alur Penelitian. 


\subsubsection{Pemilihan Sampel}

Pemilihan data sinyal mewakili data pasien penderita gangguan jantung. Diantaranya data citra jenis Aritmia Sinus, Bradikardi Sinus, Sinus Ritmi, dan Takhikardi Sinus. Citra sinyal tersebut dapat dilihat pada gambar 5 hingga 8 .

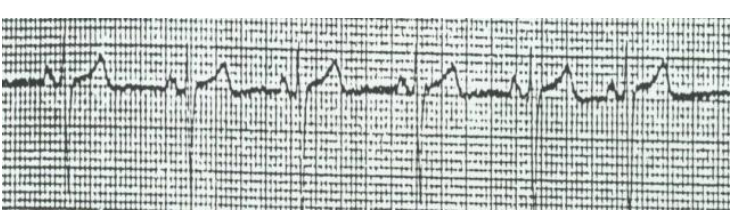

Gambar 5.Citra Aritmia Sinus.

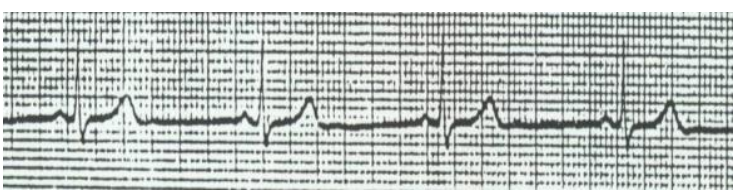

Gambar 6. Citra Bradikardi Sinus.

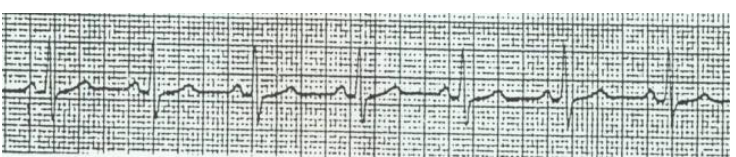

Gambar 7. Citra Sinus Ritmi.

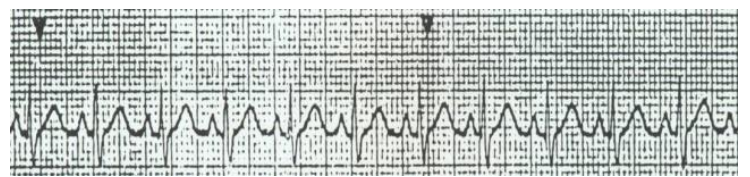

Gambar 8 Citra Takhikardi Sinus

\subsubsection{Pengolahan Citra Sinyal EKG}

Hasil pemilihan data citra sinyal kardiografi yang telah dilakukan selanjutnya dilakukan pengolahan citra. Hal ini berguna untuk memilah antara data dengan noise. Sehingga dari data pengolahan tersebut dapat lebih mudah dalam mendeteksi sinyal hasil EKG. Gambar hasil pengolahan ditunjukkan pada Gambar 9 hingga 12.

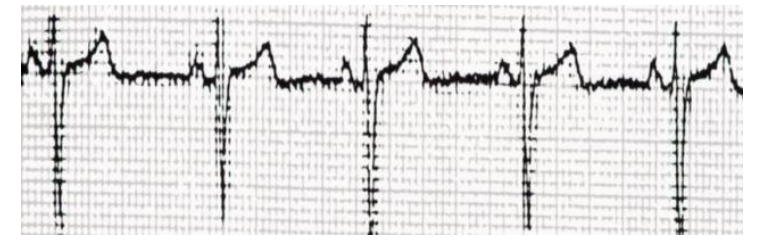

Gambar 9. Citra Hasil Pengolahan Aritmia Sinus.

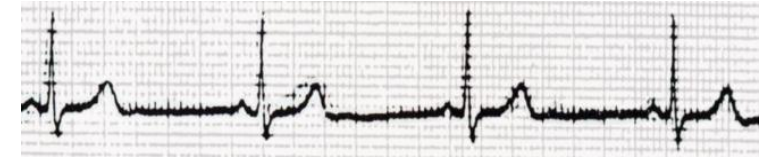

Gambar 10. Citra Hasil Pengolahan Bradikardi Sinus.

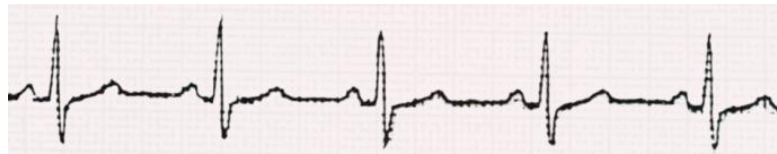

Gambar 11. Citra Hasil Pengolahan Sinus Ritmi.

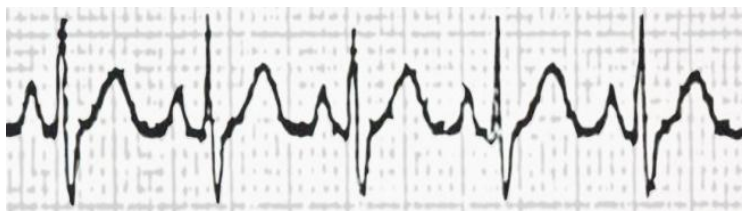

Gambar 12. Citra Hasil Pengolahan Takhikardi Sinus.

\subsubsection{Deteksi Tepi Gelombang}

Sistem deteksi tepi dengan menggunakan analisa deteksi puncak tiap gelombang yang mewakili PQRST.

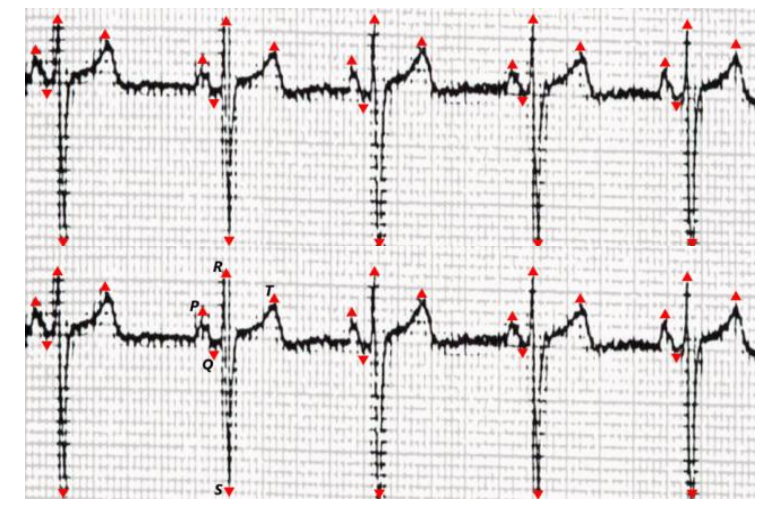

Gambar 13. Citra Hasil Deteksi Aritmia Sinus.

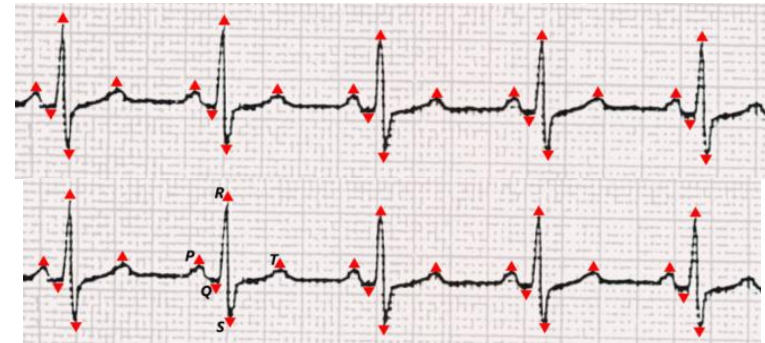

Gambar 14. Citra Hasil Deteksi Sinus Ritmi. 


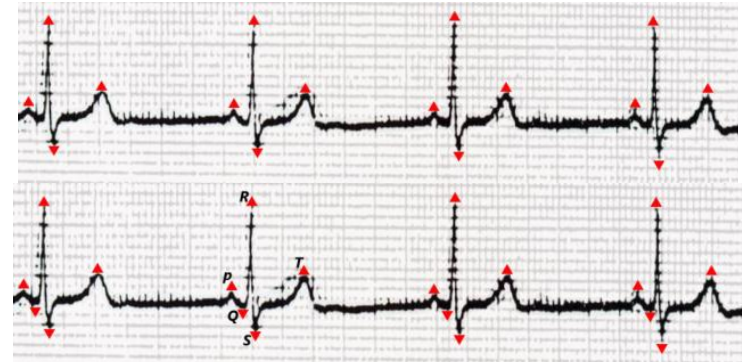

Gambar 15 Citra Hasil Deteksi Bradikardi Sinus.

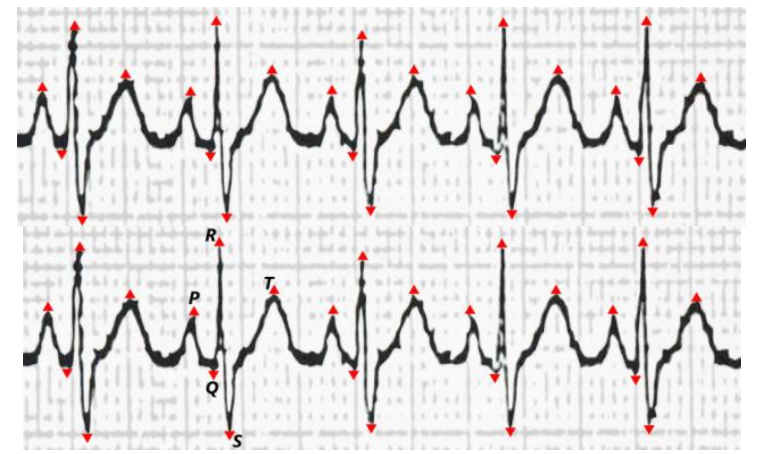

Gambar 16 Citra Hasil Deteksi Takhikardi Sinus.

\subsubsection{Analisis Hasil Deteksi}

Analisa hasil deteksi sinyal EKG diperoleh pada deteksi tepi sinyal yaitu :

1. Sinyal Aritmia Sinus

Memiliki irama tidak teratur, nilai frekuensinya (HR) antara 60 sampai dengan $100 \mathrm{X} / \mathrm{menit}$. Bentuk gelombang $\mathrm{P}$ normal yaitu lebar $\geq 0,12$ detik dan Tinggi $\leq 0,3$ miliVolt, dan gelombangnya selalu diikuti oleh gelombang QRS T. Untuk interval PR normal antara 0,12 sampai dengan 0,2 detik. Dan nilai gelombang QRS menunjukkan aktivitas normal dengan niali antara 0,06 sampai dengan 0,12 detik. Ditunjukkan pada gambar 13 sampai 16.

\section{Sinus Ritmi}

Memiliki irama teratur, dengan nilai frekuensinya (HR) 60 sampai dengan 100 $\mathrm{X} /$ menit. Dengan nilai gelombang $\mathrm{P}$ normal yaitu lebar $\geq 0,12$ detik dan Tinggi $\leq 0,3$ miliVolt, dan gelombangnya selalu diikuti oleh gelombang QRS T. Untuk interval PR normal antara 0,12 sampai dengan 0,12 detik.

\section{Bradikardi Sinus (SB)}

Memiliki irama teratur, dengan nilai frekuensi (HR) kurang dari $60 \mathrm{X} /$ menit. Dengan nilai gelombang $\mathrm{P}$ normal yaitu lebar $\geq 0,12$ detik dan Tinggi $\leq 0,3$ miliVolt, dan gelombangnya selalu diikuti oleh gelombang QRS T. Untuk interval PR normal antara 0,12 sampai dengan 0,20 detik, dan gelombang QRS nya normal dengan nilai 0,06 sampai dengan 0,12 detik.

\section{Takhikardi Sinus (ST)}

Memiliki irama teratur, dengan nilai frekuensi (HR) lebih besar dari 100 sampai dengan $150 \mathrm{X} / \mathrm{menit}$. Dengan nilai gelombang $\mathrm{P}$ normal yaitu lebar $\geq 0,12$ detik dan Tinggi $\leq 0,3$ miliVolt, dan gelombangnya selalu diikuti oleh gelombang QRS T. Untuk interval PR normal antara 0,12 sampai dengan 0,20 detik, dan gelombang QRS nya normal dengan nilai 0,06 sampai dengan 0,12 detik.

\section{KESIMPULAN}

a) Proses pengolahan sinyal kardiografi dalam arah vertikal maupun arah horisontal dapat dideteksi menggunakan lead yang terpasang pada pasien. Dengan metode ini data sinyal dapat ditentukan dalam kawasan frekuensi dan waktu.

b) Validitas sinyal hasil pemfilteran dapat diatur secara tepat dengan mengatur besarnya frekuensi pada saat melakukan pemfilteran. Pada spektrum pada dilihat hasil pengolahan citra yang lebih akurat. Sehingga nilai yang diharapkan sesuai dengan informasi dari pasien.

c) Dalam pengolahan citra dengan menggunakan sistem deteksi tepi pada gelombang QRS.

d) Dengan menggunakan melakukan proses pembatasan data memudahkan kita dalam proses pengolahan citra utamanya untuk citra gelombang kardiografi, karena pada gelombang kardiografi pola yang dihasilkan cenderung mendekati sama. Sehingga apabila metodenya 
kurang sesuai pola yang dihasilkan akan sama.

\section{DAFTAR PUSTAKA}

Aminullah Dr, Elektrokardiogram, Januari AMINCIA, 2014.

Halomoan, J, Juni 2013, Analisa Sinyal EKG dengan Metode HRV (Heart Rate Variability) pada Domain Waktu Aktivitas Berdiri dan Terlentang, Seminar Nasional Aplikasi Teknologi Informasi (SNATI), Institut Teknologi Telkom, Bandung, Indonesia, 2013.

Hariati, Nurdin W.B, Identifikasi Karakter Temporan dan Potensial Listrik Statis dari Kompleks QRS dan Segmen ST Elektrokardiogram (EKG) Pada Penderita dengan Kelainan Jantung Hipertrofi Ventrikel Kiri, Universitas Hasanuddin.

Hendriyawan, MS, Implementasi Algoritma Pendeteksian Gelombang QRS komplek pada Sistem Peringatan Kelainan Kerja Jantung Berbasis Mikrikontroler, Universitas Teknologi Yogyakarta, 2012.

Rao, R. M., Bopardikar,A.S, Wavelet Transform: Introduction to Theory and Application, Addision-Wesley, Massachusetts, 1998.

Rizal, A, Pengenalan Signal EKG Menggunakan Dekomposisi Paket Wavelet dan K-Means Clustering, SNATI Yogyakarta, 2008.

S. Grace Chang, September, Adaptive Wavelet Thresholding for Image Denoising and Compression, Student Member, IEEE, University of California, 2003.

Sofia C. OLHEDE and Andrew T. WALDEN November, 'Analytic' Wavelet Thresholding, Department of
Mathematics, Imperial College London, SW7 2AZ, London, 2003.

Utari, Pengenalan Pola Sinyal Kardiografi dengan menggunakan Alih Ragam Gelombang Singkat, Simposium RAPI XIII Universitas Muhammadiyah Malang, 2014.

Yasak, Abdul., Arifin. A., May, Ekstraksi Parameter Temporal Sinyal ECG menggunakan Difference Operation Method, The $13^{\text {th }}$ Seminar on Intelligent Technologyand Its Applications, Institus Teknologi Sepuluh November, Surabaya, Indonesia, 2012. 